\title{
Effects of abdominal sepsis in the healing of abdominal wall. Experimental study in rats $^{1}$
}

\author{
Efeitos da sepse abdominal na cicatrização de parede abdominal. Estudo experimental em \\ ratos
}

\begin{abstract}
Alexandre Malta Brandão ${ }^{I}$, Naiara Galvão da Silva ${ }^{\mathrm{I}}$, Marcos Vinícius Melo de Oliveira ${ }^{\mathrm{I}}$, Pedro Henrique Alves de Morais $\mathrm{I}$, Silvana Marques e SilvaII, João Batista de Sousa ${ }^{I I I}$, Fabiana Pirani Carneiro ${ }^{\text {IV }}$

${ }^{\mathrm{I}}$ Graduate student, School of Medicine, UnB, Brasília-DF, Brazil. Involved with technical procedures, acquisition and interpretation of data and statistical analysis and manuscript writing.

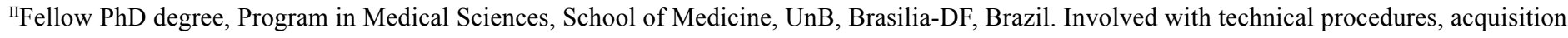
and interpretation of data, statistical analysis, critical revision and manuscript writing.

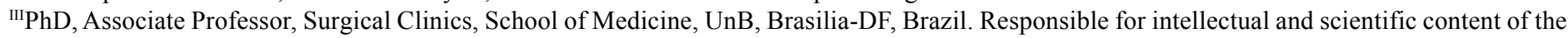
study; designed the protocol, involved with technical procedures, interpretation of data, critical revision and manuscript writing.

${ }^{\text {IV }} \mathrm{PhD}$, Associate Professor Pathology, School of Medicine, UnB, Brasilia-DF, Brazil. Macroscopic and histopathological examinations, interpretation of data and critical revision.
\end{abstract}

\begin{abstract}
PURPOSE: To evaluate the influence of sepsis in the process of wound healing in the abdominal wall.
\end{abstract}

METHODS: 40 rats divided into two groups of twenty animals: group of study (E) - septic, and the control group (C) - not septic. The two groups were divided into subgroups of 10 to be killed on the third day $(n=10)$ or seventh $(n=10)$ postoperative. Sepsis was induced by ligation and puncture of the cecum. We performed also the section and anastomosis in left colon. The synthesis of the abdominal wall was made with 3-0 silk thread. On the day of re-laparotomy, the abdominal wall was removed for analysis of the breaking strength and histopathological analysis.

RESULTS: The mean breaking strength was at third day: E group (1.44 \pm 1.22$)$ and $\mathrm{C}$ group $(0.35 \pm 0.46)$. At seventh day the mean breaking strength was: E group $(13.01 \pm 7.09)$ and $C$ group $(11.66 \pm 7.38)$. There was statistical difference in tensile strength. E group at third day with control group $(\mathrm{p}=0.019)$.

CONCLUSION: The induction of peritoneal sepsis reduced the breaking strength of the abdominal wall on the third day after surgery. Key words: Healing. Abdominal Wall. Sepsis. Tensile Strength. Rats.

\section{RESUMO}

OBJETIVO: Avaliar a influência da sepse no processo de cicatrização de feridas na parede abdominal.

MÉTODOS: 40 ratos divididos em dois grupos de vinte animais: grupo de estudo (E) - séptico, e grupo controle (C) - não séptico. Os dois grupos foram divididos em subgrupos de 10 sendo os animais mortos no terceiro $(\mathrm{n}=10)$ ou sétimo dia $(\mathrm{n}=10)$ pós-operatório. A sepse foi induzida por ligadura e punção do ceco. Foi realizada também a secção e anastomose em cólon esquerdo. A síntese da parede abdominal foi feita com fio de seda 3-0. No dia da re-laparotomia, a parede abdominal foi retirado para análise da força de ruptura e análise histopatológica.

RESULTADOS: A força média de ruptura foi: no terceiro dia, grupo $\mathrm{E}(1,44 \pm 1,22)$ e grupo $\mathrm{C}(0,35 \pm 0,46)$; no sétimo dia, grupo $\mathrm{E}$ $(13,01 \pm 7,09)$ e grupo $\mathrm{C}(11,66 \pm 7,38)$. Houve diferença estatística na resistência à tração do grupo E do terceiro dia quando comparado ao grupo controle $(\mathrm{p}=0,019)$.

CONCLUSÃO: A indução de sepse peritoneal reduziu a resistência à ruptura da parede abdominal no terceiro dia após a cirurgia. Descritores: Cicatrização. Parede Abdominal. Sepse. Resistência à Tração. Ratos. 


\section{Introduction}

Widespread infections are responsible for $10-50 \%$ of deaths in intensive care units - ICUs $-^{-1}$, due release and formation of reactive oxygen species (ROS), important in the development of septic shock ${ }^{2,3}$.

Healing is a complex process divided into phases that follow chronologically and are interposed: homeostasis, proliferative phase, contraction and remodeling. In order and practically instantly, hemostasia ${ }^{4}$ occurs first, when there is an exposure of tissue factor and collagen. Thus platelets are recruited - primary homeostasis - and the cascade of coagulation begins, activating coagulation factors and their cofactors - secondary homeostasis ${ }^{5}$.

Followed up, there is an inflammatory response called reactive phase ${ }^{5}$. The body aims to eliminate the harmful agent and try to limit tissue injury. During this phase, all signs of inflammation: pain, heat, redness and loss of function occur. The vessels dilate and the capillary permeability increases resulting in an inflammatory exudate of polymorphonuclear cells and macrophages ${ }^{6}$. The macrophages are truly essential to the healing process, since it "orchestrate" the release of cytokines that stimulates the subsequent healing process ${ }^{4,7-9}$.

Next, there is the proliferative phase characterized by angiogenesis, fibroplasias and ephithelialization ${ }^{7}$. Collagen has an important role in this healing phase, that's why it is the main responsible for the wound resistance ${ }^{8}$. Finally, wound contraction occurs, reducing the disruption of healing and scar remodeling. The contraction stems from an interaction of ECM - extracellular material - with fibroblasts. At remodeling phase there is a reduction and elimination of granulation tissue, with a reorganization of collagen, strengthening the scar.

During sepsis, there is a great oxidative stress ${ }^{10}$ that disrupts the healing process by poor collagen production and exacerbated starting immune response - inflammation ${ }^{9}$. Thus the process of repair and remodeling are interrupted, increasing the incidence of dehiscence.

The suture dehiscences of the abdominal wall are potential complications of abdominal surgeries. They are associated with high morbidity and mortality rates, aggravating the patient's condition and increasing the treatment costs ${ }^{1,11}$.

Factors that affect healing are: blood supply, the line tension, the extent of inflammation, the presence of contaminants, the patient's nutritional status and the use of drugs ${ }^{6}$.

Therefore the study of the healing process after surgical procedures in septic conditions has extreme clinical importance, since surgical dehiscence are important factor of the patient's condition, increasing morbidity and mortality. Thus, the study aims to evaluate the healing of the abdominal wall in conditions of sepsis, seeking decisive structures that affect the healing process.

\section{Methods}

The study was conducted at the Laboratory of Experimental Surgery, Faculty of Medicine, University of Brasilia - UnB. The research project was evaluated and approved by the Ethics Committee on Animal Use (CEUA) - Institute of Biological Sciences, University of Brasilia. The study was carried out within the guidelines of the Brazilian College of Animal Experiments (COBEA).

Forty male and healthy Wistar rats, Rattus norvegicus, aged between 90 and 120 days and initial body weight between 371 and $592 \mathrm{~g}$ were used. During the preoperative period, they were kept for two weeks in cages with five animals each, on a 12 hours artificial light and 12 hours darkness regimen. The rats received standard diet and water ad libitum. There was no preoperative fasting.

The animals were divided into 2 groups:

* group (E) - animals with abdominal sepsis euthanized on day $3(n=10)$ or day $7(n=10)$ after surgery;

* control group (C) - animals under physiological conditions euthanized on day $3(n=10)$ or day $7(n=10)$ after surgery.

General anesthesia was performed with xylazine hydrochloride $10 \mathrm{mg} / \mathrm{kg}$ and ketamine hydrochloride $75 \mathrm{mg} / \mathrm{kg}$ intramuscularly. All surgical procedures were performed by the same surgeon. The animals, after anesthesia, were placed on the surgical board in supine positionwith their fore and hind limbs fixed in abduction. It was performed the trichotomy of the anterior wall and antisepsis procedures with polyvinylpyrrolidone iodine.

The surgical procedure consisted in a laparotomy of $4 \mathrm{~cm}$ in length, with the distal end at $1 \mathrm{~cm}$ of the external genitalia of animals.

In group E, sepsis was induced using the method proposed by Wichterman and colleagues $(1980)^{12}$ which consists of the partial ligation of the cecum. It causes increased pressure within this segment of the intestine without ischemia and it allows free transit of intestinal contents from small intestine to the large intestine. Following, the cecum punctures were performed with venipuncture needle $40 \times 13$

In all animals, the resection of $1 \mathrm{~cm}$ segmente of the left colon was performed In all animals, the resection of $1 \mathrm{~cm}$ segment of the left colon was performed at about 2.5 to $3.5 \mathrm{~cm}$ above the peritoneal reflection. The reconstruction of intestinal transit was made by end-to-end segment anastomosis, in single transmural with continuous stitches of polypropylene 6.0 (Shalon ${ }^{\circledR}$ ) with cylindrical needle.

The synthesis of the abdominal wall was performed in two planes of continuous stitches of silk 3.0 (Shalon ${ }^{\circledR}$ ). Postoperative analgesia was performed with $0.01 \mathrm{mg}$ buprenorphine / kg subcutaneously every 12 hours. 
The animals were placed in cages where they received standard diet and water ad libitum. They were clinically evaluated for signs of infection (erection of hair, presence of diarrhea, lethargy and darkening eyes) that will be graded on the following scale: 0 -absent; 1 - mild; 2 - moderate; 3 - strong; 4- intense.

The reoperation was performed on schedule ( 3 or 7 days after the operation). The animals were anesthetized and it was performed a resection of a rectangular area at abdominal wall of 5 by $6 \mathrm{~cm}$ covering the wound. Next, we evaluated macroscopically the abdominal cavity. The animals were killed by an overdose of tionenbutal.

The study was carried out by tensile strength testing apparatus called digital VersaTest (Mecmesin Versa Test, United Kingdom) coupled to a digital dynamometer AGF (Mecmesin Versa Test, United Kingdom). The rectangular fragment of tissue was fixed at both ends by the upper clamp of the dynamometer and the bottom clamp of the Versa Test. The breaking value was expressed in Newtons (N).
Histopathology analysis was made in optical microscopy by an experienced pathologist. We evaluated the following parameters: polymorphonuclear infiltrate, mononuclear infiltrate, fibroblasts, neovascularization, collagen amount and edema. Each of these parameters was graded from 0 to 3 . It was also looked after the presence (1) or absence (0) of histopathology abscesses, foreign bodies and fibrin.

Statistical analysis was carried out using the SPSS $®$ software. To compare the groups at each assessment time, parametric and nonparametric tests was used, according to the nature of the variables. Values of $p<0.05$ indicated statistical significance.

\section{Results}

There was no significant difference between groups in weight before and after surgery. Animals from the C3, C7 and E7 showed a weight decrease in the postoperative period (Figures 1, 2 and Table 1).

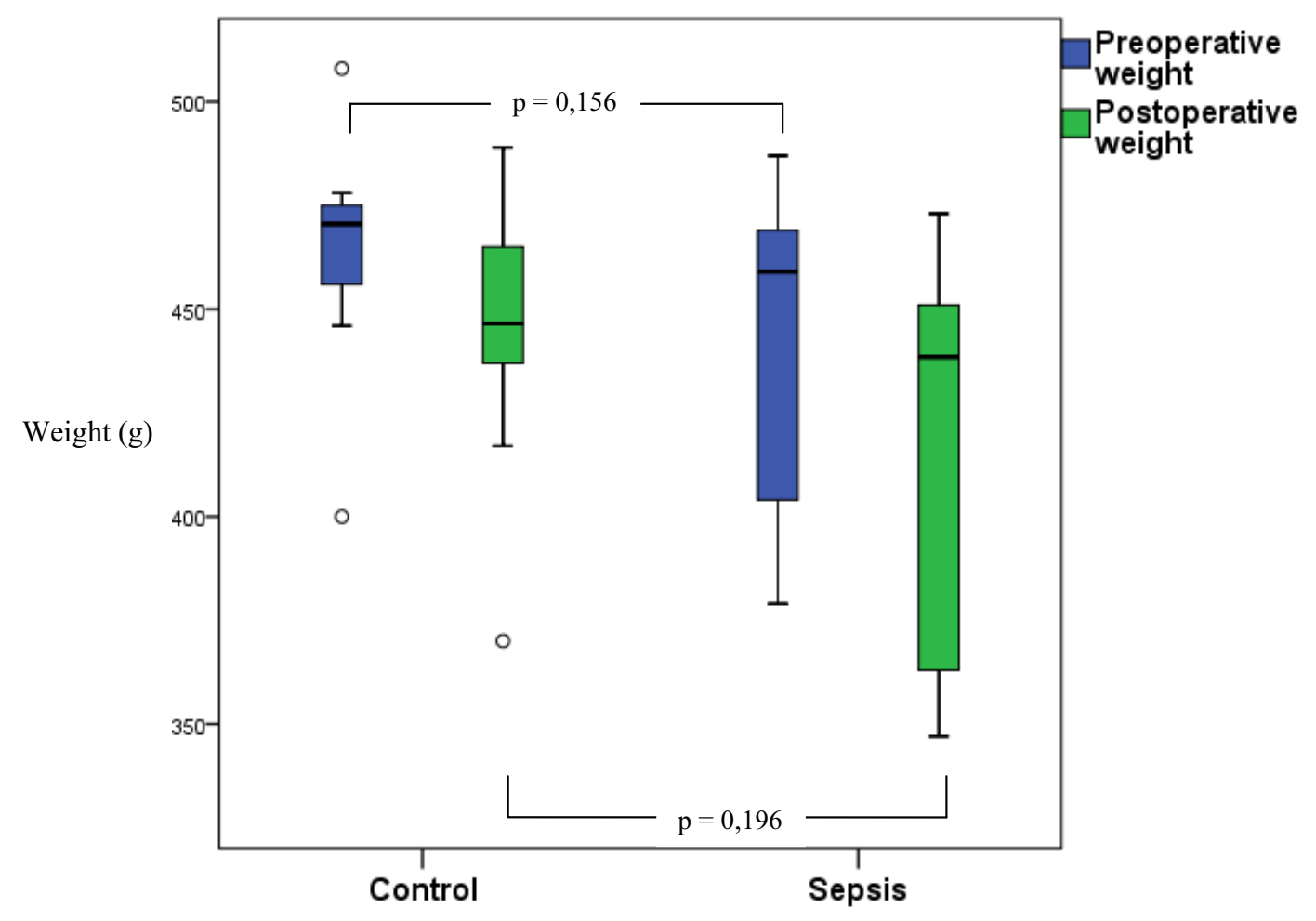

FIGURE 1 - Weight of animals euthanized on the $3^{\text {rd }}$ postoperative day 


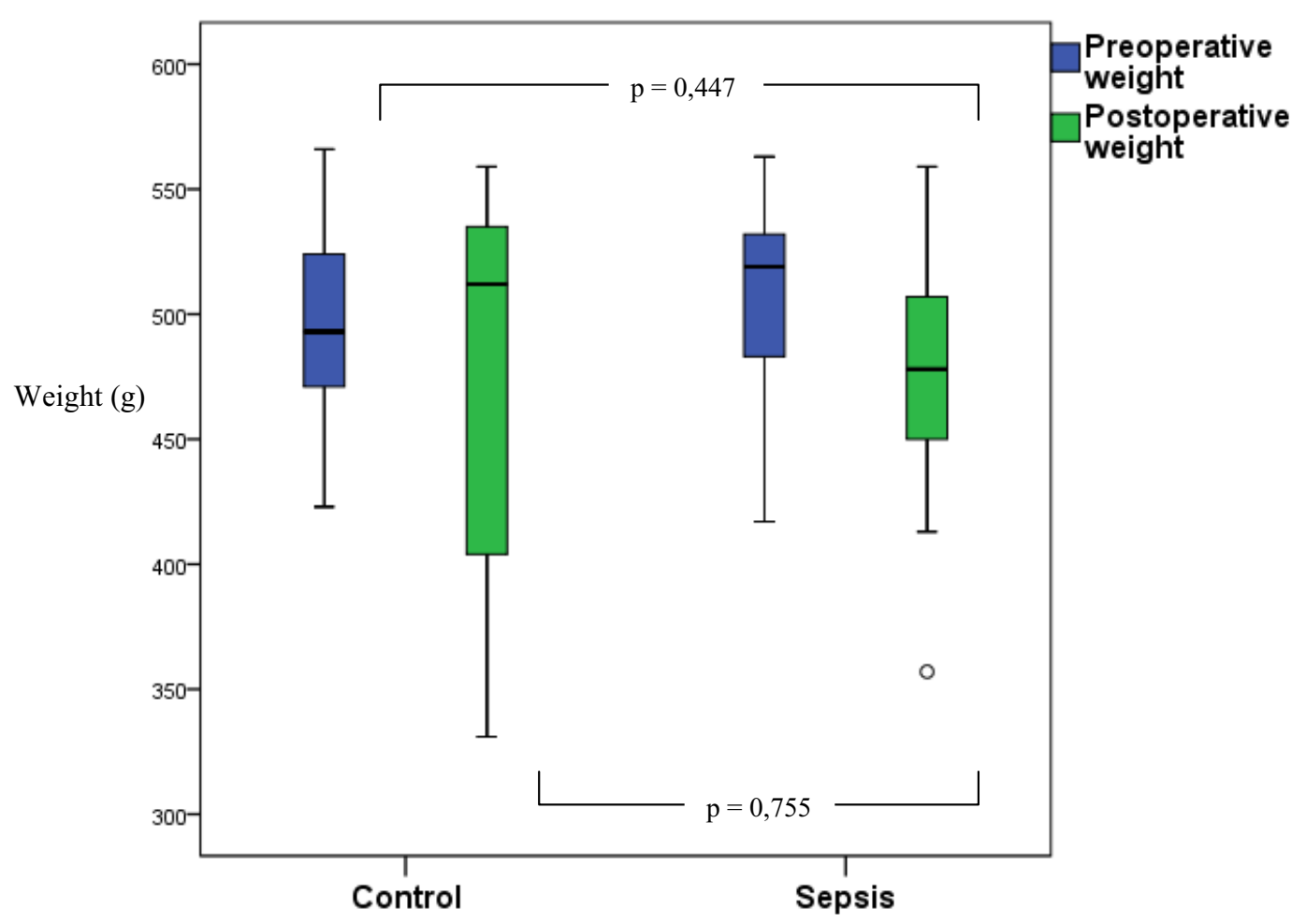

FIGURE 2 - Weight of animals euthanized on the $7^{\text {th }}$ postoperative day

TABLE 1 - Weight in grams in the preoperative period (pre weight) and postoperative (post weight)

\begin{tabular}{|c|c|c|c|c|c|c|c|c|}
\hline & \multicolumn{4}{|c|}{$3^{\text {rd }}$ Day } & \multicolumn{4}{|c|}{$7^{\text {th }}$ Day } \\
\hline & \multicolumn{2}{|c|}{ Control } & \multicolumn{2}{|c|}{ Sepsis } & \multicolumn{2}{|c|}{ Control } & \multicolumn{2}{|c|}{ Sepsis } \\
\hline & $\begin{array}{c}\text { Pre } \\
\text { Weight }\end{array}$ & $\begin{array}{c}\text { Post } \\
\text { Weight }\end{array}$ & $\begin{array}{c}\text { Pre } \\
\text { Weight }\end{array}$ & $\begin{array}{c}\text { Post } \\
\text { Weight }\end{array}$ & $\begin{array}{c}\text { Pre } \\
\text { Weight }\end{array}$ & $\begin{array}{c}\text { Post } \\
\text { Weight }\end{array}$ & $\begin{array}{c}\text { Pre } \\
\text { Weight }\end{array}$ & $\begin{array}{c}\text { Post } \\
\text { Weight }\end{array}$ \\
\hline $\mathbf{N}$ & 10 & 10 & 10 & 10 & 10 & 10 & 9 & 9 \\
\hline Maximum & 508 & 489 & 487 & 473 & 566 & 559 & 563 & 559 \\
\hline Minimum & 400 & 370 & 379 & 347 & 423 & 331 & 417 & 357 \\
\hline Mean & 464.20 & 443.1 & 442.3 & 418.9 & 492.10 & 479.6 & 507.89 & 469.44 \\
\hline Median & 470.50 & 446.5 & 459 & 438.5 & 493 & 512 & 519 & 478 \\
\hline Std. deviation & 27.856 & 32.350 & 37.565 & 46,936 & 43.406 & 77.955 & 45.015 & 59.172 \\
\hline
\end{tabular}

The clinical course of the animals was similar between groups. No rats had abdominal distention, hematoma and signs of surgical site infection. An animal of E7 group died during the study due to sepsis.

Seven animals in group E3 showed signs of peritonitis (three rats containing intra-cavitary abscesses). In the other three animals in group E3 blocked cecum was observed. There was no signs of peritonitis in the other groups. All animals in group E7 had blocked cecum.

The mean tensile strength necessary to overcome the resistance of surgical wounds in abdominal walls were: the third day study group $(1.40 \pm 1.22)$, the seventh day study group $(13.01 \pm 7.09)$; third day control group $(0.34 \pm 0.46)$, the seventh day control group (11.66 \pm 7.38$)$ (Table 2$)$.
TABLE 2 - Breaking tensile strength of animals sacrificed on the third and seventh days expressed in Newtons $(\mathrm{N})$

\begin{tabular}{lcccc}
\hline & \multicolumn{2}{c}{$\mathbf{3}^{\text {rd }}$ Day } & \multicolumn{2}{c}{$\mathbf{7}^{\text {th }}$ Day } \\
& Control & Sepsis & Control & Sepsis \\
\hline N & 10 & 10 & 10 & 9 \\
Maximum & 4.04 & 1.56 & 27.92 & 21.36 \\
Minimum & 0.03 & 0.00 & 4.21 & 1.58 \\
Mean & $1.406^{*}$ & $0.346^{*}$ & 13.014 & 11.665 \\
Median & 1.18 & 0.23 & 14.665 & 12.49 \\
Std. deviation & 1.222 & 0.458 & 7.099 & 7.378 \\
\hline
\end{tabular}

* Statistically significant difference $(p=0.015)$ by the Mann-Whitney test 
There was a statistically significant difference in tensile strength of the wound of the abdominal wall in the third day study group (E3) compared with the third day control group (C3), with $p<0.05$. There was not a statistically significant difference in tensile strength among the groups of animals from the 7th day - E7 and C7 (Figures 3 and 4).

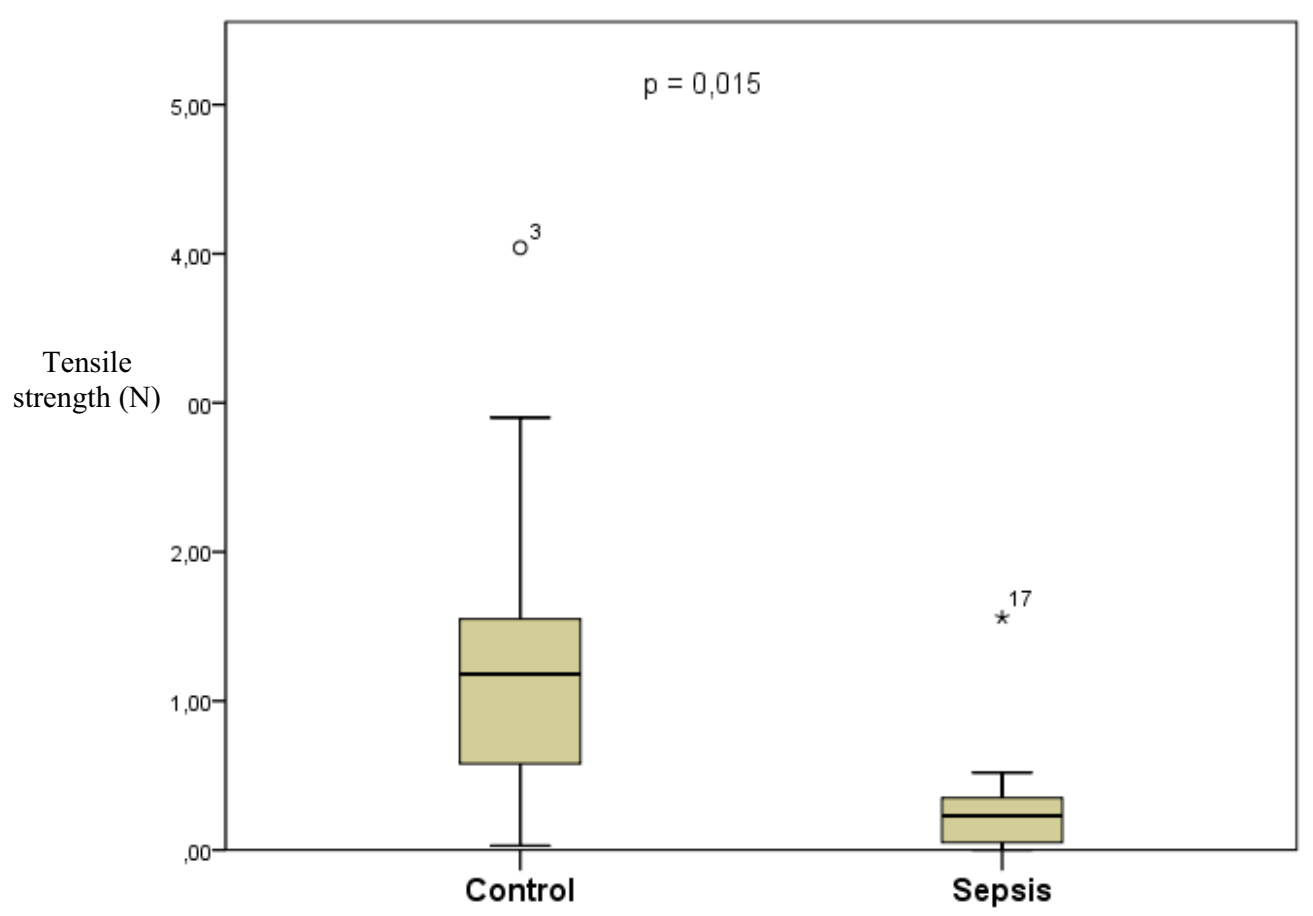

FIGURE 3 - Analysis of the breaking strength of animals euthanized on the $3^{\text {rd }}$ postoperative day

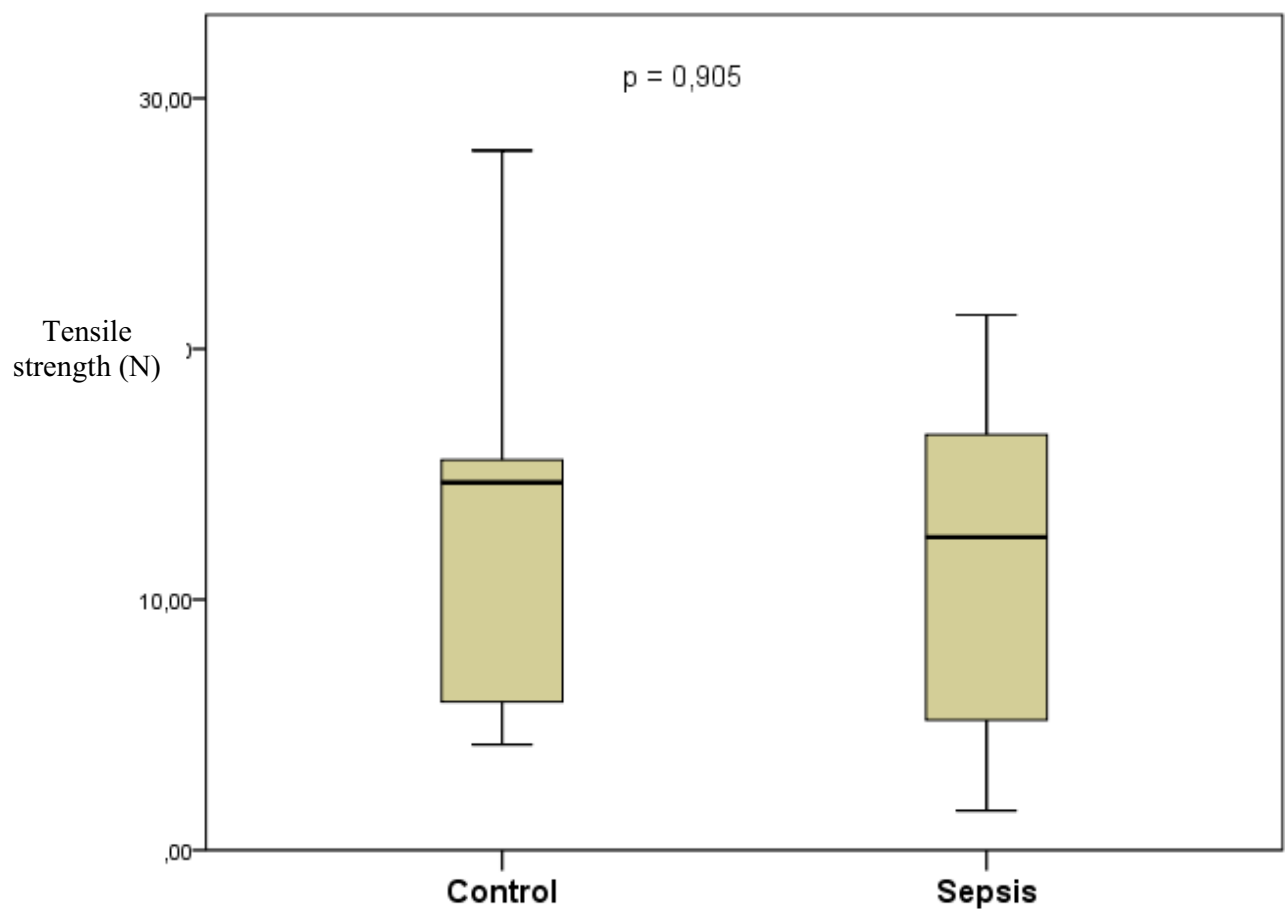

FIGURE 4 - Analysis of the breaking strength of animals euthanized on the $7^{\text {th }}$ postoperative day 
There was no statistical differences, at the Fisher's exact test, regarding histopathological parameters: polymorphonuclear infiltrate, fibroblasts, neovascularization, collagen content, histopathology abscess, foreign bodies and fibrin in all groups (Tables 3 and 4 ). The group sacrificed on the seventh day with sepsis showed more intense mononuclear infiltrate than the control group $(p=0.033)$. There was no significant difference in mononuclear infiltrate in groups of the third day - E3 e C3 (Table 3).
TABLE 3 - Median of values of the histological parameters by group

\begin{tabular}{lcccc}
\hline \multirow{2}{*}{ Parameters } & \multicolumn{2}{c}{$\mathbf{3}^{\text {rd }}$ Day } & \multicolumn{2}{c}{$\mathbf{7}^{\text {th }}$ Day } \\
& Control & Sepsis & Control & Sepsis \\
\hline Collagen & 0 & 0 & 1 & 1 \\
Fibroblasts & 2 & 2 & 3 & 3 \\
Mononuclear & 2 & 2 & $2 *$ & $3 *$ \\
Polymorphonuclear & 2 & 2 & 3 & 3 \\
Neovascularization & 2 & 2 & 3 & 3 \\
Edema & 2 & 2 & 2 & 3
\end{tabular}

* Statistically significant difference $(\mathrm{p}=0.033)$ by Fisher's exact test. Note: The histopathological analysis was divided in comparative degrees from 0 to 3 for polymorphonuclear infiltrate,mononuclear cells, fibroblasts, neovascularization, amount of collagen and edema

TABLE 4 - Number of animals by histopathological parameters divided in which group

\begin{tabular}{llcccc}
\hline \multirow{2}{*}{ Parameters } & & \multicolumn{2}{c}{$\mathbf{3}^{\text {rd }}$ Day } & \multicolumn{2}{c}{$\mathbf{7}^{\text {th }}$ Day } \\
& & Control & Sepsis & Control & Sepsis \\
\hline Histopathological abscess & Absent & 2 & 2 & 2 & 0 \\
\cline { 2 - 4 } Foreign body & Present & 8 & 8 & 8 & 9 \\
\multirow{3}{*}{ Fibrin } & Absent & 0 & 3 & 0 & 0 \\
& Present & 10 & 7 & 10 & 9 \\
& Absent & 7 & 7 & 7 & 5 \\
& Present & 3 & 3 & 3 & 4 \\
\hline
\end{tabular}

\section{Discussion}

The normal healing is a complex process in which there is cell recruitment, extracellular matrix synthesis and cell replication. Didactically cicatrization can be divided into three basic stages ${ }^{5,8}: 1$ ) acute response - from first to fourth day after the injury; 2) the proliferative phase - from fourth to the fourteenth day - and 3) phase of remodeling - from tenth day to several months. Therefore the analysis of groups of third day covered almost strictly the initial acute response to tissue injury, demonstrating values of breaking tensile strength much lower than the seventh day. In addition, during sepsis, muscle injury and acidosis lead to a release of iron present in myoglobin and hemoglobin further aggravating the framework of oxidative stress ${ }^{3,10}$. Because of the recruitment of the immune system to fight infectious agent and high oxidative stress due to infection, the healing process is deregulated ${ }^{13}$.

In this study, we found that sepsis, in the group of mice third day (E3 and C3), interfered in the process of healing on getting tensile strength of the wall (Figure 3), although there was no significant difference in histopathological analysis of the wound in which groups.

The acute phase of healing is characterized by the recruitment of platelets, exposure oftissue factor and activation and recruitment of mast cells and neutrophils ${ }^{4,11}$. Moreover, at this stage, the resistance of the wound depends on suture, as there is little collagen and these also are disorganized. Thus the resistance is gradually acquired by the migration and proliferation of fibroblasts in the healing process following steps ${ }^{4,11}$.

Although neutrophils are present in high numbers at this stage and they directly assist in the recruitment of macrophages ${ }^{4,11}$, their essential role in normal healing has been refuted. Julia V. Dovi et al. ${ }^{14}$ and Simpson et al. ${ }^{15}$ showed that wounds in rats with low neutrophil function and low concentrations of neutrophils exhibited more rapid reepithelialization. In these studies, there were not loss in tensile strength of the wall or disorganization in collagen content of the wound, since neutrophils produce proteases that inactivate bioactive substances pro-healing and induce direct tissue injury. By contrast, neutrophils also produce a variety of growth factors and cytokines that promote tissue repair ${ }^{4,11}$. Thus, the role of the neutrophil is ambivalent and it may be positive or negative for the healing process.

Because of the intense inflammatory process of sepsis, there are increased recruitment and activation of polymorphonuclear cells, leading to greater action of neutrophils. Thus the balance would hang to the neutrophil's downside: intense production of bioactive substances and proteinases that could disrupt the healing process ${ }^{5}$.

The lower resistance observed in the E3 group compared to that observed in $\mathrm{C} 3$ (Figure 3 ) could demonstrate an activity 
of neutrophils more exacerbated due tosystemic inflammatory process. Although there was a significant difference in the number of polymorphonuclear cells in histopathology between these two groups (Table 4), sepsis in the organism shows a large amount of circulating pro-inflammatory cytokines whose capacity of stimulating neutrophil activity is well documented.

Corroborating to increased activation of neutrophils in the reactive phase of E3, group of seventh day with sepsis (E7) had higher mononuclear cells than its control (C7). Although some studies indicate a secondary role of neutrophils in macrophage migration in wound healing ${ }^{11}$, the ability of neutrophil's chemotaxis in increasing migration of macrophages is incontestable ${ }^{5,11}$. Thus the higher activity of neutrophils could have increased migration of macrophages in the group E7 ${ }^{5,11}$.

As the later stages of healing - proliferative and remodeling - do not depend on function or concentration of neutrophils ${ }^{11,14,15}$, the tensile strength obtained by the wound in the groups of the seventh day (E7 and C7) has no significant difference between them.

In addition, all animals in groups of seventh day had blocked their cecum. It indicates that their organism has begun to contain the infection caused by the process of sepsis induction in this study (cecum perforation). Therefore the systemic inflammatory process in these rats would be decreased. Then these animals are tending to cure the sepsis. Thus the group of seventh day could have less interference on healing process than what it was observed in the group of third day.

\section{Conclusion}

Induction of peritoneal sepsis reduced the breaking strength of the abdominal wall as measured on the third day after surgery, but did not affect the tensile force on the seventh day and the histopathological findings.

\section{References}

1. Brun-Buisson C. The epidemiology of the systemic inflammatory response. Intensive Care Med. 2000;26:S64-74.

2. Goode HF, Howdle PD, Walker BE. Decreased antioxidant status and increased lipid peroxidation in patients with sepsis and secondary organ dysfunction. Crit. Care Med.1995;23:646-51.

3. Zhang H, Slutsky AS, Vincent JL. Oxygen free radicals in ARDS, septic shock and organ dysfunction. Intensive Care Med. 2000;26:474-6. 4. Cray C, Zaias J, Altman NH. Acute phase response in animals: a review. Comp Med. 2009;59:517-26.

5. Wilgus TA. Immune cells in the healing skin wound: Influential players at each stage of repair. Pharmacol Res. 2008;58:112-6.

6. Sousa JB, Oliveira PG. Cuidados com a ferida operatória: infecção. Clin Cir Bras. 1999;5:215-37.

7. Kumar I, Staton CA, Cross SS, Reed MW, Brown NJ. Angiogenesis, vascular endothelial growth factor and its receptors in human surgical wounds. Br J Surg. 2009;96:1484-91.

8. Schilling JA. Wound healing. Surg Clin North Am.1976;56:859-74.

9. Martin CW, Muir IFK. The role of lymphocytes in wound healing. $\mathrm{Br}$ J Plast Surg.1990;43:655-65.

10. Linares A, Nakao LA, Augusto O. EPR studies of in vivo radical production by lipopolysaccharidade: Potencial role of iron mobilized from iron-nitrosyl complexes. Free Radic Biol Med. 2003;34:766-73.

11. Braiman-Wiksman L, Solomonik I, Spira R, Tennenbaum T.Novel insights into wound healing sequence of events. Toxicol Pathol. 2007;35:767-79.

12. Wichterman KA, Baue AAAE, Chaudry IH. Sepsis and septic shock - a review of laboratory models and a proposal. J Surg Res. 1980;28:189-201.

13. Gomes SC, Campos ACL, Torres OJM, Vasconcelos PRL, Moreira ATR, Tenório SB, Tâmbara EM, Sakata K, Moraes HJ, Ferrer ALS. Efeito do extrato de Passiflora Edulis na cicatrização da parede abdominal de ratos: estudo morfológico e tensiométrico. Acta Cir Bras. 2006;21:9-16. 14. Dovi JV, He LK, Dipietro LA. Accelerated wound closure in neutrophil-depleted mice. J Leukoc Biol. 2003;73:448-55.

15. Simpson DM, Ross R. The neutrophilic leukocyte in wound repair: a study with antineutrophil serum. J Clin Invest. 1972;51:2009-23.

\section{Correspondence:}

João Batista de Sousa

Campus Universitário Darcy Ribeiro

Prédio da Reitoria, $2^{\circ}$ pavimento, sala B2-16

70910-900 Brasília - DF Brasil

Tel.: (55 61)3307-2201

sousajb@unb.br

Conflict of interest: none

Financial source: none

${ }^{1}$ Research performed at Experimental Laboratory of Surgery, Faculty of Medicine, University Hospital of Brasilia (UnB), Brasilia, DF, Brazil. Presented at the XII National Congress on Experimental Surgery of the Brazilian Society for Development of Research in Surgery-SOBRADPEC, 2011 October 26-29 Ribeirao Preto-SP, Brazil. 